\title{
STUDIES ON THE QUANTITATIVE EVALUATION OF CERTAIN TREATMENTS IN THE HEALING OF EXPERI- MENTAL THIRD DEGREE BURNS ${ }^{1}$
}

\author{
By C. MARTIN RHODE,2 MANUEL F. MORALES, ${ }^{3}$ AND EUGENE L. LOZNER 4 \\ (From the Naval Medical Research Institute, National Naval Medical Center, \\ Bethesda, Maryland)
}

(Received for publication October 13, 1944)

The number of local treatments which have been proposed for burns is legion. In one exhaustive review of the subject (1), some sixty pages are devoted to this phase. It is obvious, however, that there is in the surgical mind little satisfaction with these treatments because, at not infrequent intervals, medications continue to be suggested for topical application to burned surfaces. It was one such report (2) which prompted the investigations to be presented below.

Although attempts at quantification of wound healing and the effects upon it of certain treatments have been made in the past ( 3 to 7 ), to our knowledge such attempts have never been applied to an evaluation of treatment of the third degree burn including its excision. From all accounts, expedition of healing of the third degree burn presents a major challenge to therapy. Excision of such an area has been performed at numerous times in the past (1). It was perhaps first performed in 1901 (8). In 1913, two workers (9) believed that by such a procedure survival of the burned animal could be prolonged. It was decided, therefore, to investigate systematically the healing of the experimental third degree burn and the effect thereon of several treatments including excision, and to apply to the data obtained the newer knowledge of growth quantification (10).

1 This 'article has been released for publication by the Division of Publications of the Bureau of Medicine and Surgery of the U. S. Navy. The opinions and views set forth in this article are those of the writers and are not to be considered as reflecting the policies of the Navy Department.

2 Lieutenant (jg), Medical Corps, United States Naval Reserve.

8 Ensign, H-V(S), United States Naval Reserve.

4 Lieutenant Commander, Medical Corps, United States Naval Reserve.

\section{METHODS}

Adult rabbits weighing between 5 and 9 pounds were used. Standard third degree burns were made on the backs of rabbits according to the technique of Leach et al. (11), using an asbestos-jacketed cylinder through which hot water circulates. The burning surface of the cylinder was a circle one inch in diameter, and the burning temperature was 75 to $82^{\circ} \mathrm{C}$. for 1 minute.

There were 3 general types of experimental procedure carried out following the burn. The first of these was upon a group of 20 burns in which no treatment was administered. The second group consisted of 54 cases in which some medicament or graft was applied immediately following the burn; in $\mathbf{1 3}$ of these, the application was made directly on the burn, and in the other 41 , to the surface left following excision of the burn. The excision line was usually through the area of edema just beyond the coagulum. Despite this conservative approach, the retraction of the wound usually led to an area double that of the third degree burn. Finally, the third group consisted of $\mathbf{5}$ donor areas (Table I).

The coagulated plasma-sulfonamide film of Pollock (2), hereinafter known as CPS, was applied in 13 cases to the burned area, and in 15 cases to the surface remaining after the burn had been excised.

Other reagents applied to the surfaces left by excision of the burn included vaseline (13 cases), thrombinfibrinogen-sulfonamide (5 cases), and a "diazifilm" (1 case).

Grafts were attempted in 7 cases but did not succeed for various reasons, chief among which was sepsis. Both whole and split-thickness grafts on both whole and splitthickness excision surfaces were tried.

Bandaging septic excisions led to early gross infection, maceration, and destruction of tissue with a punched out appearance, but improvement occurred almost immediately upon exposure to air. Cultures were not attempted. In sterile experiments, the bandages were rarely left on after 14 to 16 days. Within this time, infection did not occur. Thus, medication was never in apposition to the wound longer than this time.

Observations on the course of regeneration were made approximately every third day from the time the burn was made to the time of complete regeneration. The measurement of the unhealed area was made with a centimeter ruler. The surfaces were regarded as roughly elliptical in shape, whence the area was taken to be 
$\pi r_{1} r_{2}$, where $r_{1}$ and $r_{2}$ are, respectively, the semi-major and semi-minor axes of the ellipse.

The measurement of the unhealed area mentioned above can be converted into a suitable growth measurement as follows: Let $a(0)$ denote the original area of the wound surface. Let $a(t)$ denote the remaining unhealed area after $t$ days. Then obviously $a(0)-a(t)$ represents the amount of tissue regenerated. The CarrelHartman (3) observation that, in equal times, the growth increment of a large wound is greater than that of a small wound is very likely attributable to the use of just $a(0)-a(t)$ as the parameter of growth. This measure can give the impression that the fundamental proliferation mechanisms proceed at different rates in wounds of different sizes. As a matter of fact, the "percentage growth rates" are the same regardless of size. It is preferable therefore to put large and small wounds on an even footing, so to speak, and use instead of amount regenerated, the

$$
\left\{\begin{array}{l}
\text { Fraction of the original } \\
\text { wound which has been } \\
\text { regenerated up to time } t
\end{array}\right\}=\frac{a(0)-a(t)}{a(0)}=P
$$

Assuming that area is proportional to some function of cell numbers, $P$ also represents the fraction of the total number of cells which have been produced to time t. In terms of this parameter, then, differences among growth curves will arise only from fundamental differences in the mechanism of growth, rather than from mere size difference of the wounds.

From the experimental data for each regeneration, it is possible to compute $\mathbf{P}$ at every experimental point. For days other than days of observation, one may obtain an approximation to $\mathbf{P}$ by a linear interpolation. Thus, it becomes possible to plot "mean growth curves" for large numbers of areas by plotting average values of $P$ at a given time. The mean curves thus obtained are remarkably regular, and very well suited for comparative purposes.

\section{RESULTS AND DISCUSSION}

Two comparisons of the mean curves for controls with excised areas, and areas treated with vaseline with areas treated with CPS have been

TABLE I.

This table summarizes all experiments considered in the text.

The upper number of each entry is $A$, the per cent rate of growth, while the lower number is proportional to $B$, the interactive coefficient. Every entry represents about eight observations of one growth curve. Burning time is given in minutes, and burning temperature in degrees Centigrade. Abbreviations are as follows: CPS = coagulated plasma-sulfonamide film; Thr.-Fibr. = thrombin-fibrinogen.

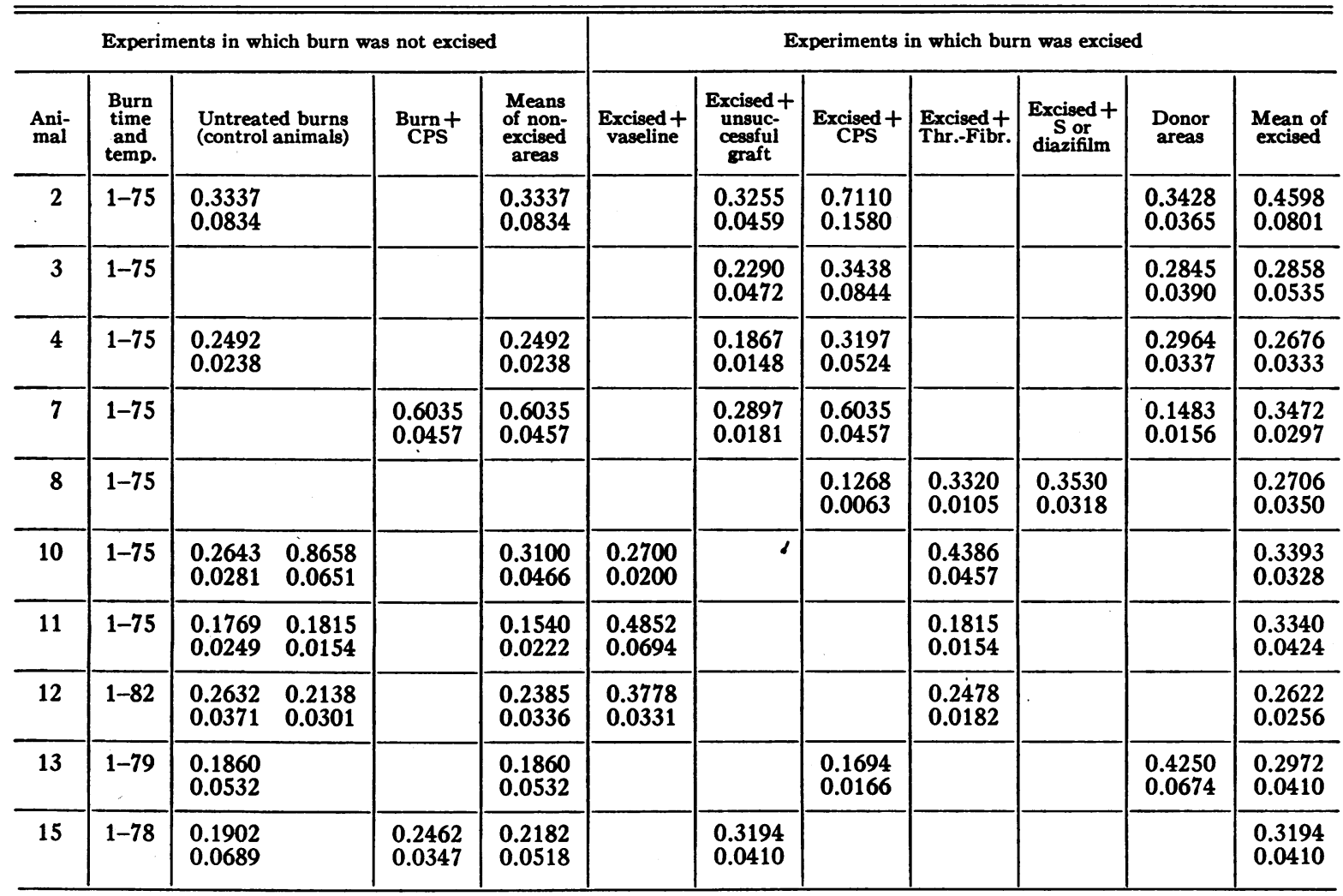


TABLE I-Continued

\begin{tabular}{|c|c|c|c|c|c|c|c|c|c|c|c|}
\hline \multicolumn{5}{|c|}{ Experiments in which burn was not excised } & \multicolumn{7}{|c|}{ Experiments in which burn was excised } \\
\hline$\underset{\text { mal }}{\text { Ani- }}$ & $\begin{array}{c}\text { Burn } \\
\text { time } \\
\text { and } \\
\text { temp. }\end{array}$ & $\begin{array}{l}\text { Untreated burns } \\
\text { (control animals) }\end{array}$ & $\underset{\text { CPS }}{\text { Burn }}$ & $\begin{array}{l}\text { Means } \\
\text { of non- } \\
\text { excised } \\
\text { areas }\end{array}$ & $\begin{array}{l}\text { Excised + } \\
\text { vaseline }\end{array}$ & $\begin{array}{c}\text { Excised+ } \\
\text { unsucuc- } \\
\text { cessful } \\
\text { graft }\end{array}$ & $\underset{\text { CPS }}{\text { Excised }}+$ & $\begin{array}{l}\text { Excised + } \\
\text { Thr.-Fibr. }\end{array}$ & $\begin{array}{c}\text { Excised + } \\
\text { sor or } \\
\text { diazifilm }\end{array}$ & $\begin{array}{l}\text { Donor } \\
\text { areas }\end{array}$ & $\begin{array}{l}\text { Mean of } \\
\text { excised }\end{array}$ \\
\hline 16 & $1-78$ & & $\begin{array}{l}0.3160 \\
0.0479\end{array}$ & $\begin{array}{l}0.3160 \\
0.0479\end{array}$ & & $\begin{array}{l}0.1335 \\
0.0152\end{array}$ & & & & & $\begin{array}{l}0.1335 \\
0.0152\end{array}$ \\
\hline 17 & 1-82 & $\begin{array}{l}0.1920 \\
0.0315\end{array}$ & $\begin{array}{l}0.2962 \\
0.0338\end{array}$ & $\begin{array}{l}0.2441 \\
0.0326\end{array}$ & $\begin{array}{l}0.3879 \\
0.0269\end{array}$ & & $\begin{array}{l}0.3753 \\
0.0232\end{array}$ & & & & $\begin{array}{l}0.3816 \\
0.0250\end{array}$ \\
\hline 18 & $1-82$ & $\begin{array}{l}0.2897 \\
0.0742\end{array}$ & $\begin{array}{l}0.3713 \\
0.0742\end{array}$ & $\begin{array}{l}0.3300 \\
0.0742\end{array}$ & $\begin{array}{l}0.2111 \\
0.0169\end{array}$ & & $\begin{array}{l}0.3073 \\
0.0240\end{array}$ & & & & $\begin{array}{l}0.2592 \\
0.0204\end{array}$ \\
\hline 19 & $1-80$ & $\begin{array}{l}0.2965 \\
0.0582\end{array}$ & $\begin{array}{l}0.2273 \\
0.0394\end{array}$ & $\begin{array}{l}0.2619 \\
0.0438\end{array}$ & $\begin{array}{l}0.1903 \\
0.0134\end{array}$ & & $\begin{array}{l}0.2170 \\
0.0143\end{array}$ & & & & $\begin{array}{l}0.2037 \\
0.0138\end{array}$ \\
\hline 20 & $1-80$ & $\begin{array}{l}0.1335 \\
0.0243\end{array}$ & $\begin{array}{l}0.1707 \\
0.0265\end{array}$ & $\begin{array}{l}0.1521 \\
0.0254\end{array}$ & $\begin{array}{l}0.2145 \\
0.0101\end{array}$ & & $\begin{array}{l}0.2090 \\
0.0108\end{array}$ & & & & $\begin{array}{l}0.2102 \\
0.0104\end{array}$ \\
\hline 21 & $1-80$ & $\begin{array}{l}0.2187 \\
0.0370\end{array}$ & $\begin{array}{l}0.1541 \\
0.0270\end{array}$ & $\begin{array}{l}0.1864 \\
0.0320\end{array}$ & $\begin{array}{l}0.3020 \\
0.0213\end{array}$ & - & $\begin{array}{l}0.3050 \\
0.0354\end{array}$ & & & & $\begin{array}{l}0.3030 \\
0.0286\end{array}$ \\
\hline 22 & $1-80$ & $\begin{array}{l}0.1989 \\
0.0301\end{array}$ & $\begin{array}{l}0.1834 \\
0.0171\end{array}$ & $\begin{array}{l}0.1911 \\
0.0236\end{array}$ & $\begin{array}{l}0.3387 \\
0.0204\end{array}$ & & & & $\begin{array}{l}0.2383 \\
0.0161\end{array}$ & & $\begin{array}{l}0.2885 \\
0.0182\end{array}$ \\
\hline 24 & $1-80$ & & & & & $\begin{array}{l}0.3970 \\
0.0269\end{array}$ & & & & & $\begin{array}{l}0.3970 \\
0.0269\end{array}$ \\
\hline 27 & $1-81$ & $\begin{array}{l}0.2395 \\
0.0406\end{array}$ & $\begin{array}{l}0.1080 \\
0.0204\end{array}$ & $\begin{array}{l}0.1737 \\
0.0305\end{array}$ & $\begin{array}{l}0.6040 \\
0.0300\end{array}$ & & $\begin{array}{l}0.4020 \\
0.0490\end{array}$ & & & & $\begin{array}{l}0.5030 \\
0.0390\end{array}$ \\
\hline 28 & $1-81$ & $\begin{array}{l}0.1645 \\
0.0257\end{array}$ & $\begin{array}{l}0.1382 \\
0.0216\end{array}$ & $\begin{array}{l}0.1504 \\
0.0237\end{array}$ & $\begin{array}{l}0.2620 \\
0.0136\end{array}$ & & $\begin{array}{l}0.3100 \\
0.0131\end{array}$ & & & & $\begin{array}{l}0.2865 \\
0.0134\end{array}$ \\
\hline 30 & $1-81$ & $\begin{array}{l}0.2390 \\
0.0328\end{array}$ & $\begin{array}{l}0.1865 \\
0.0338\end{array}$ & $\begin{array}{l}0.2130 \\
0.0332\end{array}$ & $\begin{array}{l}0.4310 \\
0.0194\end{array}$ & & $\begin{array}{l}0.2210 \\
0.0095\end{array}$ & & & & $\begin{array}{l}0.3258 \\
0.0144\end{array}$ \\
\hline 31 & $1-81$ & $\begin{array}{l}0.2780 \\
0.0421\end{array}$ & $\begin{array}{l}0.2490 \\
0.0377\end{array}$ & $\begin{array}{l}0.2630 \\
0.0399\end{array}$ & $\begin{array}{l}0.1800 \\
0.0132\end{array}$ & & $\begin{array}{l}0.2830 \\
0.0130\end{array}$ & & & & $\begin{array}{l}0.2320 \\
0.0131\end{array}$ \\
\hline \multicolumn{2}{|c|}{$\begin{array}{l}\text { Total } \\
\text { numbers }\end{array}$} & 20 & 13 & 19 & 13 & 7 & 15 & 4 & 2 & 5 & 22 \\
\hline
\end{tabular}

made (Figures 1 and 2, respectively). Each circle on the graphs represents the mean of a stated number $(\mathrm{N})$ of observations. The smooth curves are theoretical curves to be discussed presently. From these comparisons two important inferences are made: (1) that healing proceeds significantly faster when the burned area is excised, and (2) that CPS has no effect on healing which differs from the effect of an inert reagent, such as vaseline. In all instances, it will be observed that the curves are typical simple growth curves, symmetric about $\mathrm{P}=50$ per cent and showing no discontinuities. To further document these remarks now requires a second step in the analysis of the data.

The contrast between the general properties of two growths can be brought into sharper focus by an elementary theoretical treatment. This is particularly true when the growth of a more or less homogeneous tissue is considered, for then the growth curve can be linked to certain basic factors in cell economy. Thus, if, as has been done (10), we postulate that the

$\left\{\begin{array}{l}\text { Rate of } \\ \text { growth } \\ \text { of cells }\end{array}\right\}=\left\{\begin{array}{c}\text { Intrinsic proliferation } \\ \text { rate of non-inter- } \\ \text { acting cells }\end{array}\right\}-\left\{\begin{array}{c}\text { Effect of inter- } \\ \text { actions among } \\ \text { cells }\end{array}\right\}$,

we may form a simple theory (12) to account for the growth of a homogeneous colony so that:

$$
\left\{\begin{array}{c}
\text { Intrinsic proliferation } \\
\text { rate of non-interacting } \\
\text { cells }
\end{array}\right\}=\text { (constant) } \times \mathrm{N}=\mathrm{AN}
$$

$$
\begin{gathered}
\left\{\begin{array}{c}
\text { Effect of } \\
\text { interactions } \\
\text { among cells }
\end{array}\right\}=- \\
=-\left\{\begin{array}{l}
\text { Effect of nutri- } \\
\text { tional and excre- } \\
\text { tional interactions }
\end{array}\right\}-\left\{\begin{array}{c}
\text { Effect of } \\
\text { spatial } \\
\text { interactions }
\end{array}\right\} \\
=-\mathrm{BN}^{2}-\mathrm{CN}^{3}
\end{gathered}
$$


where $\mathrm{N}$ is cell number, and $\mathrm{A}, \mathrm{B}$, and $\mathrm{C}$ are socalled vital coefficients (13). Putting these together we obtain the differential equations of the growth as,

$$
\frac{\mathrm{dN}}{\mathrm{dt}}=\mathrm{AN}-\left(\mathrm{BN}^{2}+\mathrm{CN}^{3}\right)
$$

Although the factor $C$ is usually small, it introduces considerable mathematical difficulty (12) into the application of equation (1), and furthermore requires a greater number of experimental points than is here furnished.

However, the simpler form of (1)-omitting the C-originally proposed by Robertson (14), though with a different interpretation (autocatalysis), can be easily applied to give comparative estimates regarding $\mathrm{A}$ and $\mathrm{B}$. The integral form of (1) can be written as,

$$
\frac{N}{N(\infty)}=\frac{1}{1+K e^{-\Lambda t}} \text {, and } B=\frac{A}{N(\infty)}
$$

As remarked above, $\mathrm{N} / \mathrm{N}(\infty)=(\mathrm{a}(\mathrm{0})-$ $a(t)) / a(0)$. Substituting into (2) and rearranging, we have

$$
\log \frac{a(t)}{a(o)-a(t)}=-A t+\log K,
$$

from which it follows that $A$, the per cent rate of growth of non-interacting cells, can be obtained as the negative of the slope of $a \log _{e}(a(t) /(a(0)$ $-\mathrm{a}(\mathrm{t}))$ vs. $\mathrm{t}$. Then $\mathrm{B}$, the coefficient of retardation due to interactions such as competition or possibly infection can be found from (2), at least up to a constant of proportionality.

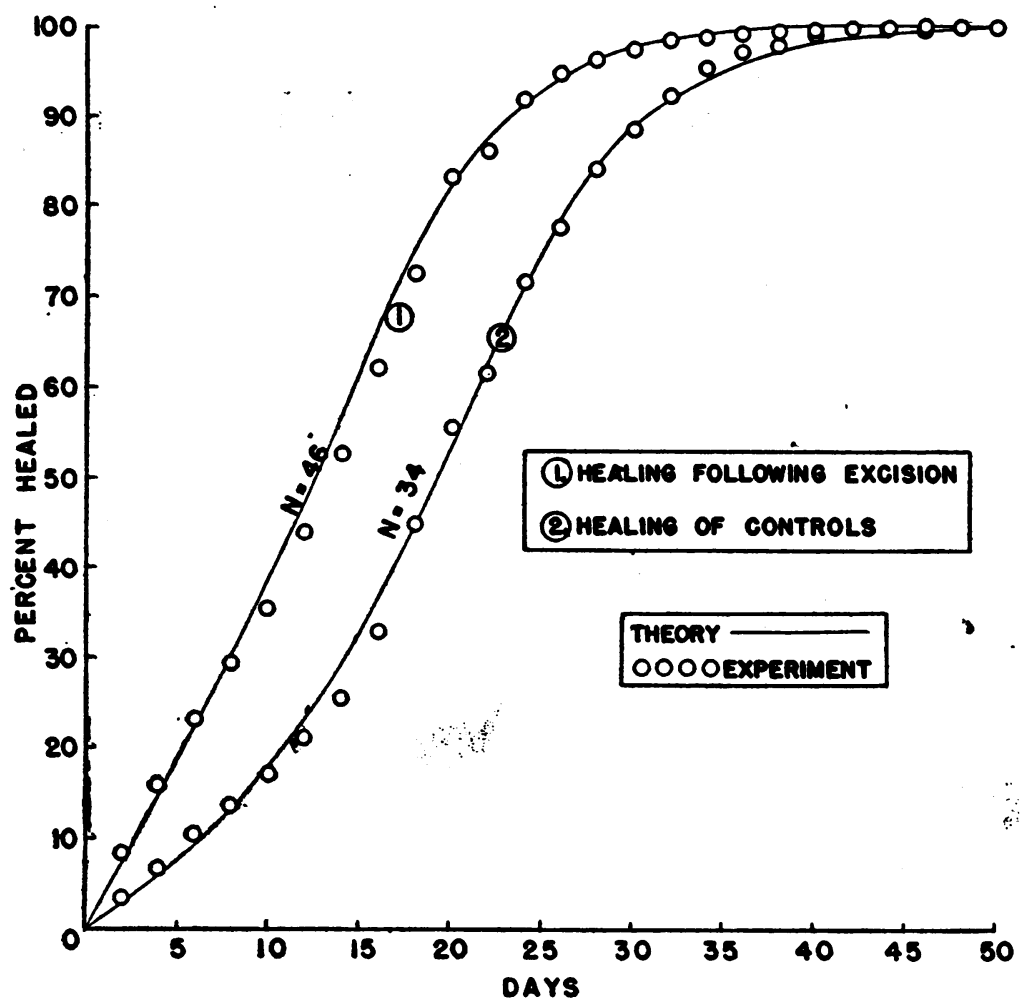

Fig. 1. Comparison of the Effect of Excision (Curve-1) with Non-Excision (Curve-2)

Each circle is the mean of the specified number $(\mathrm{N})$ of experiments. The theoretical curves are, respectively, $P=100 /\left(1+70 e^{-0.108 t}\right)$, and $P=$ $100 /\left(1+192 e^{-0.177 t}\right)$, and are derived from the theory of growth of homogeneous cell populations (see text). 


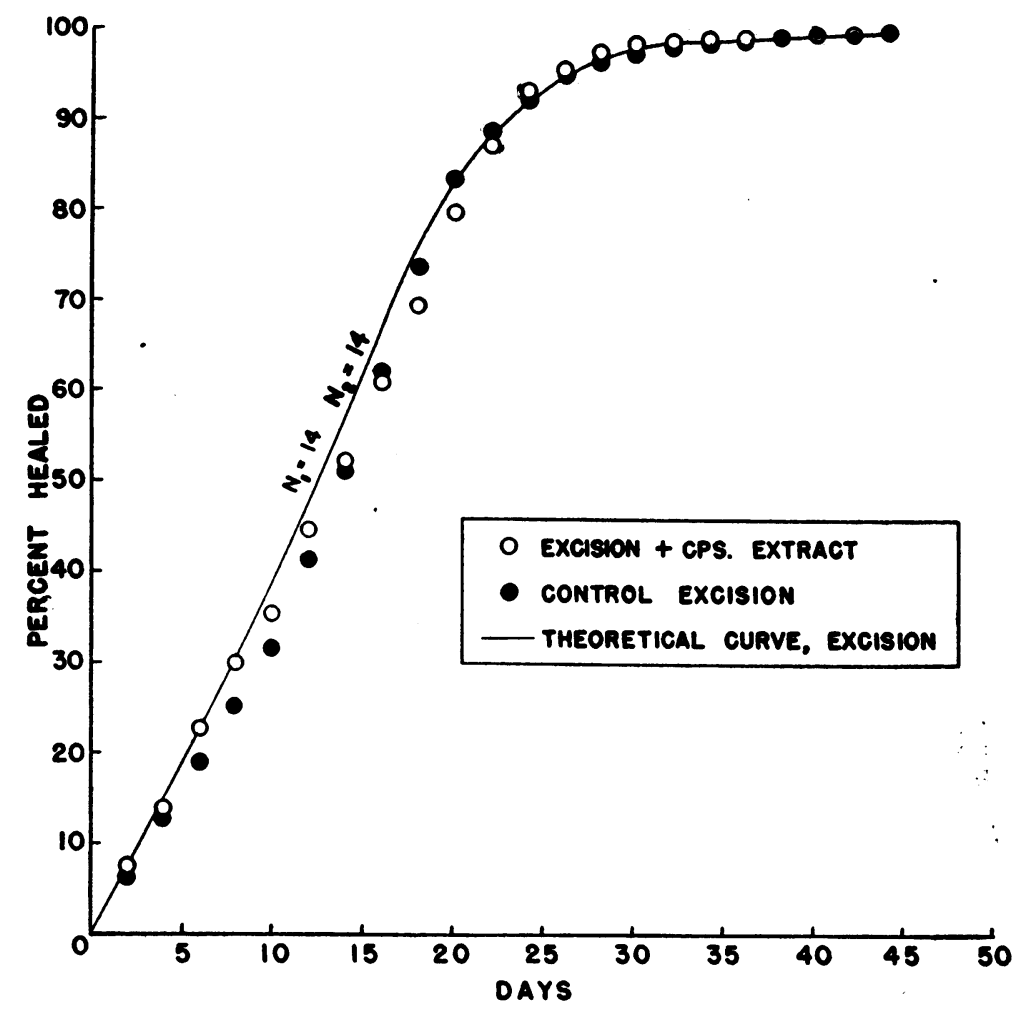

Fig. 2. Illustration of the Failure of CPS in Affecting the Curve of Healing

Each white and black point is the mean of 14 paired observations. The control excisions were surfaces coated with vaseline. The theoretical curve is the mean theoretical curve for the healing of any excision surface, $P=100 /\left(1+70 e^{-0.198 t}\right)$.

Equation (2) has been applied and $\mathrm{A}$ and $\mathrm{B}$ have been determined in each of 79 cases with encouraging results. A typical plot of equation (3) appears in Figure 3. In the great majority of cases, the equation was followed with precision, from which fact it can be inferred that the healing phenomenon, or perhaps the limiting process of the phenomenon, closely resembles the growth of a more or less homogeneous cell population. Such an over-enthusiastic interpretation of this result can be easily challenged on histological grounds. For example, the contraction of a collagen network may be largely responsible for the closing of a wound, and this process in turn may be paced by the migration of fibroblasts from a regenerating blood supply. The possibility remains, however, that either or both of these agencies may be regarded as homogeneous populations of units whose function is contributing directly to the closure of the wound rim, and hence obeying the law of equation (2). Obviously, the present experiments cannot give the final answer to this question; yet it would be unwise to overlook the suggestions which arise from them. Quite aside from the question of mechanism, it should be emphasized that the constants $\mathrm{A}$ and $\mathrm{B}$, as theoretically determined, measure respectively a per cent rate of growth and an inhibitory interaction amongst the growing tissue. They are mathematical consequences of the experimental data, and are as real as the data.

The evaluation of these constants (Table I) has been applied to yield certain interesting results such as the frequency distributions of $A$ and $B$ for various experimental conditions (Figure 4).

In the comparison of excised burns with control burns, it appears that no statistically significant difference exists between the proliferation rates 


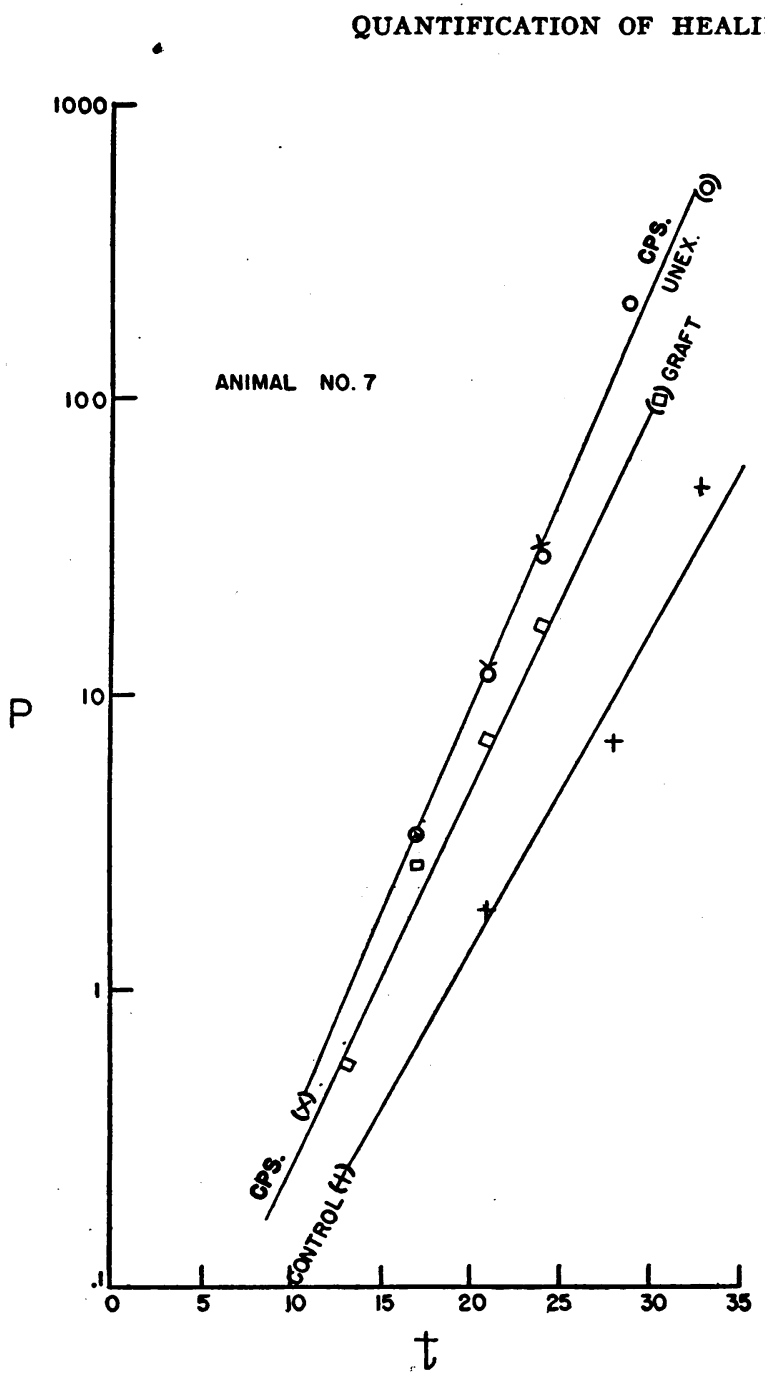

Fig. 3. A Typical Plot (Animal No. 7) of LoG $[a(t) /(a(0)-a(t))]$ vs. $t$

Actually the values of the argument of the logarithm have been plotted on a semilogarithmic grid. Tangents of the angles of inclination can be multiplied by 0.1382 to yield logarithmic slopes to the base $e$.

(A's) in the two cases, but there is only one chance in $500(t=3.16 ; \mathrm{P}<2$ per cent $)$ that the difference in the average $B$ 's for the two groups will be quite accidental. Thus, keeping in mind the precautions discussed above, we may say tentatively that the average per cent proliferation rate following an unexcised burn is not significantly lower than the rate following excision, but that on the other hand, the inhibitory interactions are far greater when the burn is not excised. The failure to detect any change in the per cent proliferation rate does not support the concept that the burned tissue releases some growth-depressing substance.

The other frequency distributions (Figure 4) further emphasize the fact that the CPS has no effect either on A or on B when applied directly to the burn, or following excision. It is quite possible that the favorable observations made on this extract were on other than third degree burns. The determination of the degree of the burn in the present investigation was unequivocal.

A glance at the growth constants for the other reagents, e.g., sulfonamide, diazifilm, or graftdonor (Table I), will show that within our data no difference can be said to exist between them and the constants for the vaseline-treated wounds.

\section{SUM MARY}

1. The rates of epithelization of experimental third degree burns treated by various methods have been determined and analyzed according to newer knowledge of growth formulas.

2. The superiority of a coagulated plasmasulfonamide film as a therapeutic agent in the treatment of third degree burns over other agents has not been substantiated in this investigation.

3. Surgical excision of a small third degree burn in rabbits significantly shortens its healing time. The main effect of this treatment seems to be in the removal of inhibitory cell interactions rather than on the proliferation rate.

4. Vaseline and sulfanilamide, thrombinfibrinogen, and plasma sheets applied to these surgical wounds seem to have approximately the same effect on regrowth as does no medication.

5. The curve of healing of both control and excised burns follows the growth curve of a homogeneous cell colony with high precision.

Lieutenant (jg) C. Martin Rhode, MC-V(S), USNR, had completed experimental work of this report before leaving for service with the Amphibious Forces. He had also left a clear outline of the interpretation of the work. From this and from numerous discussions with him, we have tried to set forth his findings and opinions in a suitable manner. However, responsibility for any of the shortcomings in the present report must rest with us (M. F. M., E. L. L.).

For very helpful statistical and pathological counsel, we are indebted respectively to Lieutenant (jg) J. E. Birren, H-V(S), USNR, and Lieutenant I. Gersh, H-V(S), USNR. 

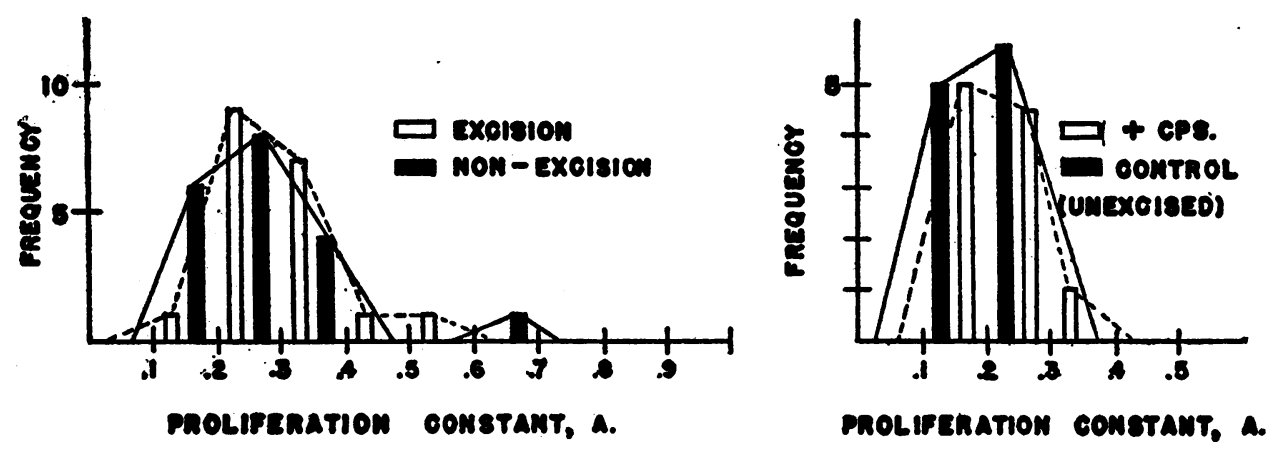

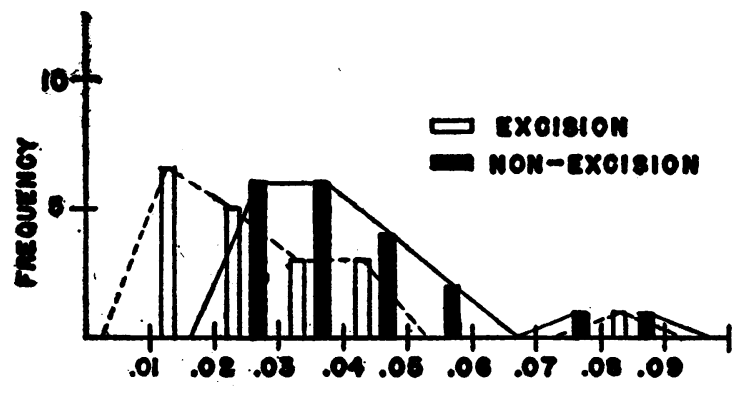

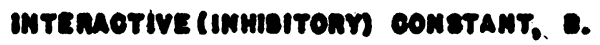

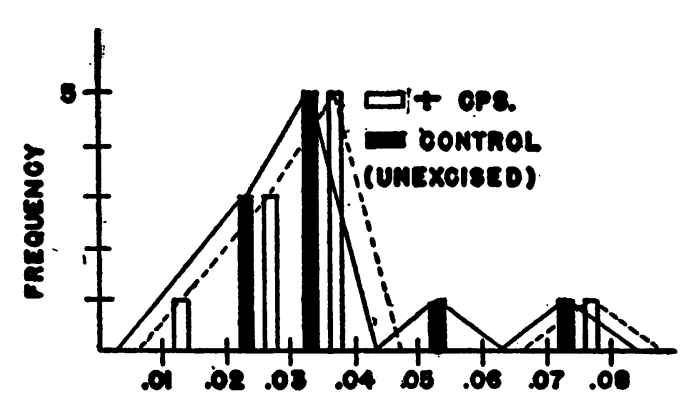

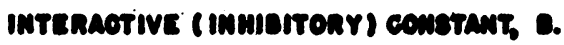
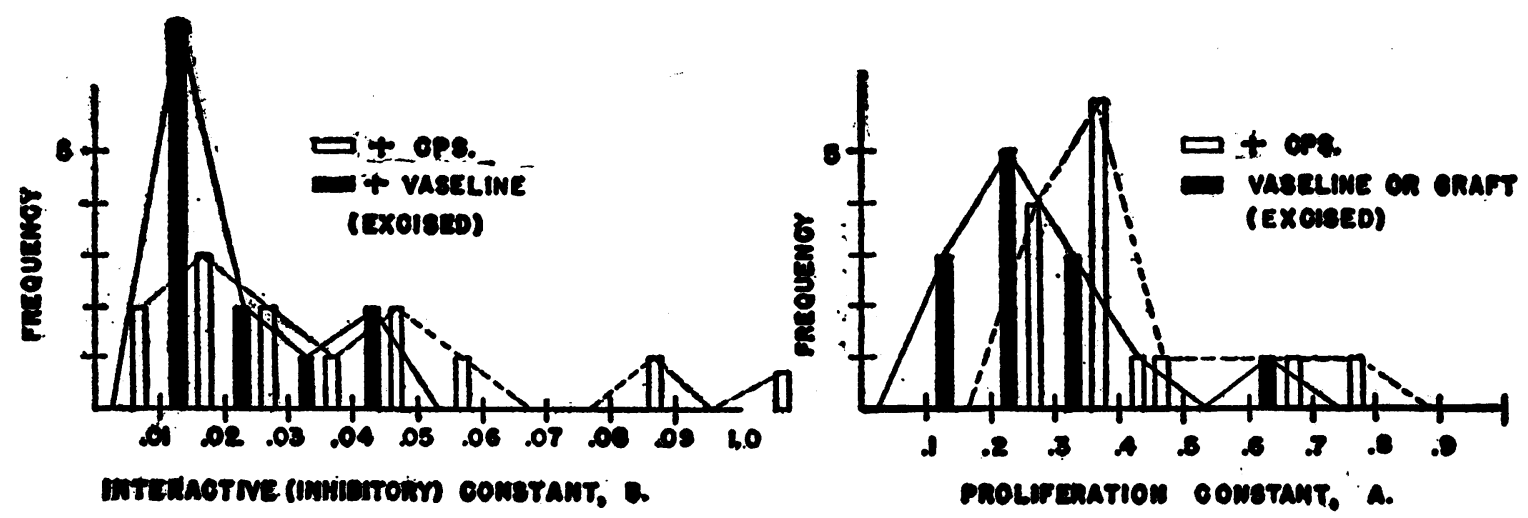

Fig. 4. Histograms Illustrating the Distribution of Growth Constants A (Per Cent Rate of Proliferation), and B (Interactive Constant) in the Course of Certain Experimental Comparisons

No distributions are significantly different except those for $B$ in the comparison, excision vs. non-excision. 
It is a pleasure to acknowledge the able assistance of R. L. Erickson, PhMlc, V-6, USNR, in the performance of the experimental work and the preparation of the manuscript.

Many thanks are due W. S. Terus, PhMlc, V-6, USNR, for the design and preparation of the charts appearing in this report.

\section{BIBLIOGRAPHY}

1. Harkins, H. N., Treatment of Burns. Charles C. Thomas, Springfield, 1942.

2. Pollock, B., I. Dried plasma sheets in treatment of burns. II. Dried plasma sheets in the treatment of war wounds. U. S. Nav. M. Bull., 1944, 42, 1171.

3. Carrel, A., and Hartman, A., Cicatrization of wounds. I. The relation between the size of a wound and the rate of its cicatrization. J. Exper. Med., 1916, 24, 429.

4. Du Noüy, P. L., Cicatrization of wounds. II. Mathematical expression of the curve representing cicatrization. J. Exper. Med., 1916, 24, 451.

5. Carrel, A., and Du Noüy, P. L., Cicatrization of wounds. XI. Latent period. J. Exper. Med., 1921, 34, 339.

6. Brush, B. E., and Lam, C. R., The effect of the topical application of several substances on the healing of experimental cutaneous wounds. Surgery, 1942, $12,355$.

7. Cannon, B., and Cope, O., Rate of epithelial regeneration. Ann. Surg., 1943, 117, 85.

8. Wilms, M., Studien zur Pathologie der Verbrennung. Mitt. a.d. Grenzgeb. d. Med. u. Chir., 1901, 8, 393.

9. Heyde, and Vogt, Studien über die Wirkung des aseptischen chirurgischen Gewebszerfalles and Versuche über die Ursachen des Verbrennungstodes. Ztschr. f. d. ges. Med., 1913, 1, 59.

10. Morales, M. F., and Shock, N. W., A fundamental form for the differential equation of colonial and organism growth. Bull. Math. Biophys., 1942, 4, 63.

11. Leach, E. H., Rossiter, R. J., and Peters, R. H., Observations upon thermal burns. Medical Research Council: War wounds committee, subcommittee on burns, B. S. 14, Report No. 2 (British).

12. Morales, M. F., and Kreutzer, F. L., Nutritional and excretional interactions and the growth of an organ or colony. Bull. Math. Biophys., In press.

13. Kostitzin, V. A., Mathematical Biology. Harrap, London, 1939.

14. Robertson, T. B., The analysis of the growth of the normal white mouse into its constituent processes. J. Gen. Physiol., 1926, 8, 463. 